\title{
QUEEN'S
UNIVERSITY
BELFAST
}

\section{What use is qualitative research?}

Dornan, T., \& Kelly, M. (2017). What use is qualitative research? Medical Education, 51(1), 7-9.

https://doi.org/10.1111/medu.13229

\author{
Published in: \\ Medical Education
}

Document Version:

Peer reviewed version

Queen's University Belfast - Research Portal:

Link to publication record in Queen's University Belfast Research Portal

\section{Publisher rights}

(C) 2016 John Wiley \& Sons Ltd and The Association for the Study of Medical Education

This is the peer reviewed version of this article, Dornan, T. and Kelly, M. (2017), What use is qualitative research?. Medical Education, 51: 7-9. which has been published in final form at http://onlinelibrary. wiley.com/wol1/doi/10.1111/medu.13229/abstract. This article may be used for non-commercial purposes in accordance with Wiley Terms and Conditions for Self-Archiving.

\section{General rights}

Copyright for the publications made accessible via the Queen's University Belfast Research Portal is retained by the author(s) and / or other copyright owners and it is a condition of accessing these publications that users recognise and abide by the legal requirements associated with these rights.

Take down policy

The Research Portal is Queen's institutional repository that provides access to Queen's research output. Every effort has been made to ensure that content in the Research Portal does not infringe any person's rights, or applicable UK laws. If you discover content in the Research Portal that you believe breaches copyright or violates any law, please contact openaccess@qub.ac.uk. 
What use is qualitative research?

Tim Dornan and Martina Kelly

'Our aim is to publish studies with more definitive-not exploratory-research questions that are relevant to an international audience and that are most likely to change clinical practice and help doctors make better decisions. We do not prioritise qualitative research because qualitative studies are usually exploratory by their very nature and do not provide generalisable answers. ${ }^{1}$

Seventy-six senior academics recently signed a letter asking BMJ to look more favourably on qualitative research ${ }^{2}$. The editors declined ${ }^{1}$. Other major clinical journals view qualitative research equally unfavourably'. This 'State of the Science' issue on methodology, however, shows that Medical Education is unwaveringly committed to it ${ }^{3456}$. Our aim is to help readers reconcile those opposing stances.

The wording of BMJ's stance is informative. Its editors have to 'make hard decisions on just how interesting an article will be to ... general clinical readers, how much it adds, and how much practical value it will be' ${ }^{\prime 2}$. Characterising 'interesting articles' as 'definitive', 'generalisable', able to 'change practice', and helping clinicians 'make better decisions' describes effectiveness research. 'Effective' practitioners choose between clearly defined alternatives. They need clear, numerical outcomes; not words. Appealing. But HL Mencken said 'there is always a well-known solution to every human problem - neat, plausible, and wrong. ${ }^{\prime 7}$

Donald Schön called neat, plausible, effective interventions 'technical rationality'. Implementing those interventions in the face of social complexity and inequality is in Schön's 'swampy lowlands', where complexity, uncertainty, instability, uniqueness, and value-conflict prevail ${ }^{8}$. Qualitative research inhabits swampy lowlands. Does education? Even clinical practice?

Five $^{3-6,9}$ articles in this issue describe swampy ways of knowing and researching. Two ${ }^{4,9}$ cite Bruner's distinction between paradigmatic, or general, and narrative, or particular, knowledge. A science of replicable steps and generalisable findings generates paradigmatic knowledge. Paying attention to particularities - individual and contextual factors - that make one situation or experience different from another generates narrative knowledge. Humanities rather than science cater for particularities ${ }^{9}$. Narrative knowledge helps clinicians handle uncertainties and ambiguities that paradigmatic knowledge cannot.

What these articles ${ }^{3-6,9}$ state implicitly is that the whole mess of humanity, and not just neat technical solutions, are legitimate topics of education inquiry. Two $0^{5,9}$ even hint that Mencken's aphorism is applicable to clinical as well as education research.

One article ${ }^{5}$ broadens the discussion from effectiveness to impact. Having acknowledged that effectiveness research helps use scant resources fairly, it argues that the impact of qualitative 
research comes from clarifying ${ }^{10}$ relationships between cause and effect ${ }^{5}$. It 'advocates for a nuanced approach to demonstrating impact in the field ${ }^{5}$. In Regehr's words ${ }^{11}$, this re-orientates research from an imperative of proof towards an imperative of understanding. Representing complexity well by, for example, showing how the discipline of surgery empowers men over women ${ }^{12}$ may not prove effectiveness. But it could have far-reaching social impact.

Many of the world's greatest current problems - war, terrorism, mass migration, and an upsurge in populist politics in western democracies - result from an unequal distribution of power, privilege, and opportunity. As medical education globalises, its leaders will increasingly have to understand and respond to instability and value-conflict of this typ ${ }^{13}$. Qualitative research provides a tool - critical discourse analysis ${ }^{6}$ - to help them do so.

We will impact education if we are methodologically eclectic: identifying and framing problems; exploring solutions; and justifying choices on grounds of socially defensible values as well as effectiveness. The qualitative methodologies in Medical Education's 2017 State of the Science issue show how exploratory research can have impact to which effectiveness research is blind.

Qualitative research will deliver those benefits in a Utopia where researchers choose methodologies judiciously. Senior ones will be willing to lay positivist assumptions aside and learn humbly from juniors. Methodological experts will welcome non-experts into their worlds. Experts and novices will listen attentively to lay people, patients, and members of other disciplines.

We have contrasted two temporal trends: Medical Education's liberal one, which is eclectic; and a conservative one, which increasingly privileges paradigmatic over narrative knowledge. Utopians will 'represent complexity well' ${ }^{11}$ by following the liberal trend. They will respond sympathetically to, even embrace, unfamiliar epistemologies described in this issue. They will celebrate the move of qualitative research beyond emergent themes. They will abandon triangulation, member checking, and saturation as arbiters of rigour ${ }^{3}$. They will avoid the word 'jargon' when researchers co-author biographical encounters with patients ${ }^{4}$, think with stories ${ }^{4}$, and depart from educational problematics ${ }^{5}$. They will take uncomfortable conclusions about power, privilege, and opportunity seriously, even when confronted with bewildering niceties of discourse analysis ${ }^{6}$. This issue of Medical Education shows plenty that is useful about qualitative research. Let's build Utopia now!

\footnotetext{
${ }^{1}$ Loder E, Groves T, Schroter S, Merino JG, Weber W. Qualitative research and The BMJ. BMJ 2016; 352: i641 doi: 10.1136/bmj.i641

${ }^{2}$ Greenhalgh T, Annandale E, Ashcroft R et al. An open letter to The BMJ editors on qualitative research. BMJ 2016;352:i563 doi: 10.1136/bmj.i563

${ }^{3}$ Varpio L, Ajjawi R, Monrouxe L, O'Brien B, Rees C. Shedding the cobra effect: problematizing thematic emergence, triangulation, saturation and member checking. Medical Education 2017;
} 
${ }^{4}$ Clandinin DJ, Cave MT, Berendonk C. Narrative Inquiry: A relational research methodology for medical education. Medical Education 2017;

${ }^{5} \mathrm{Ng}$ SL, Bisaillon L, Webster F. Using institutional ethnography to inquire into health professions education and practice. Medical Education 2017;

${ }^{6}$ Unknown authors. The interplay of text, meaning and practice: methodological considerations on discourse analysis in medical education. Medical Education 2017;

${ }^{7}$ Mencken HL. The Divine Afflatus. In: Mencken HL. 1921. Prejudices Second Series. London: Jonathan Cape, 1921. p158

${ }^{8}$ Schön D. The Reflective Practitioner. 1983. New York: Basic Books

${ }^{9}$ Unknown authors. Knowing how we know: an epistemological rationale for the medical humanities. Medical Education 2017;

${ }^{10}$ Cook D, Bordage G, Schmidt H. Description, justification and clarification: a framework for classifying the purposes of research in medical education. Medical Education 2008; 42: 28-33

${ }^{11}$ Regehr G. It's NOT rocket science: rethinking our metaphors for research in health professions education. Medical Education 2010; 44: 31-9

${ }^{12}$ Hill E, Vaughan S. The only girl in the room: How paradigmatic trajectories deter female students from surgical careers. Medical Education 2013; 47: 547-56

${ }^{13}$ Norcini J, Banda S. Increasing the Quality and Capacity of Education: The Challenge for the 21st Century. Medical Education 2011; 45: 81-6 